\title{
Not all Tears Imply Sadness: A Concise Review on the Impact of Modern Radiotherapy Techniques in Preventing Radiation Induced Xerophthalmia
} Irfan Ahmad ${ }^{1}$, Kundan Singh Chufal ${ }^{2 *}$ and Chandi Prasad Bhatt ${ }^{1}$

${ }^{1}$ Department of Radiotherapy, Batra Hospital \& Medical Research Centre, Tughlakabad Institutional Area, New Delhi, India ${ }^{2}$ Department of Radiotherapy, Rajiv Gandhi Cancer Institute \& Research Centre, Rohini, New Delhi, India

Keywords: Xerophthalmia; Dry Eye Syndrome; Gray; Ocular toxicity Introduction

The orbit is a complex region with respect to its architectural anatomy and physiological function. The tissues of the eye and orbit are trigerminal in embryonic origin and are composed of several discrete structures functioning in harmony [1]. Consequently, a diverse spectrum of neoplasms can arise within and around this relatively small region and damage to even a single normal structure leads to consequential adverse effects. While surgical intervention is often necessary to manage neoplasms arising in and around this region, radiotherapy (RT) and chemotherapy are also indicated in selected cases [1]. Due to the small size and multitude of normal structures, a wide range of side-effects can occur as a result of intentional or unintentional irradiation of the orbit, which is further complicated by varying radiation sensitivity of each structure. The purpose of this article is to summarize the literature on radiation induced xerophthalmia (dry eye syndrome) and the impact of modern radiotherapy techniques to prevent this complication.

Dry Eye Syndrome (DES) is defined by the International Dry Eye Workshop as a "multi-factorial disease of the tears and ocular surface that results in symptoms of discomfort, visual disturbance, and tear film instability with potential damage to the ocular surface accompanied by increased osmolarity of the tear film and inflammation of the ocular surface" [2]. Damage to the lacrimal functional unit is implicated as the cause of DES [3,4]. It is comprised of the main lacrimal gland, accessory lacrimal glands (Krause \& Wolfring), conjunctival goblet cells and epithelial cells of the cornea and conjunctiva. The overall physiological function of these structures is to produce the tear film, which is composed of aqueous, mucinous and lipid components, as shown in Figure 1. Radiation induced damage to the lacrimal functional unit leads to tear film instability and reduced surface tension resulting in an evaporative dry state $[4,5]$. This results in xerophthalmia, secondary damage to cornea and conjunctiva, which if not addressed could also lead to loss of vision or ocular perforation (Figure 2) [4-6].

The probability of DES is dose-dependent and increases with increasing radiation dose (Table 1 ). This may be related to varying radiation sensitivities of the different subunits of the lacrimal functional unit. Atrophy of meibomian glands and conjunctival goblet cells occurs at doses less than $30 \mathrm{~Gy}$, whereas the lacrimal gland atrophy occurs at higher doses $[7,8]$. Till date, researchers have attempted to correlate the dose received by the main lacrimal gland and DES but there is a growing appreciation of the multi-factorial process involved in the pathogenesis of DES attributable not just to the main lacrimal gland but also to numerous other structures of the ocular apparatus [6-8]. A few series have reported on rate of RT induced DES in patients treated for ocular lymphoma and these provide data on the lower end of the dose spectrum. In the series reported by Kennerdell et al, 54 patients were treated with RT dose between 24-25.5 Gray (Gy) utilizing conventional fractionation [9]. They reported acute and chronic DES in 50\% and $33 \%$ of patients, respectively. Another series by Stafford et al composed of 48 patients, reported mild chronic DES in $25 \%$ of patients and

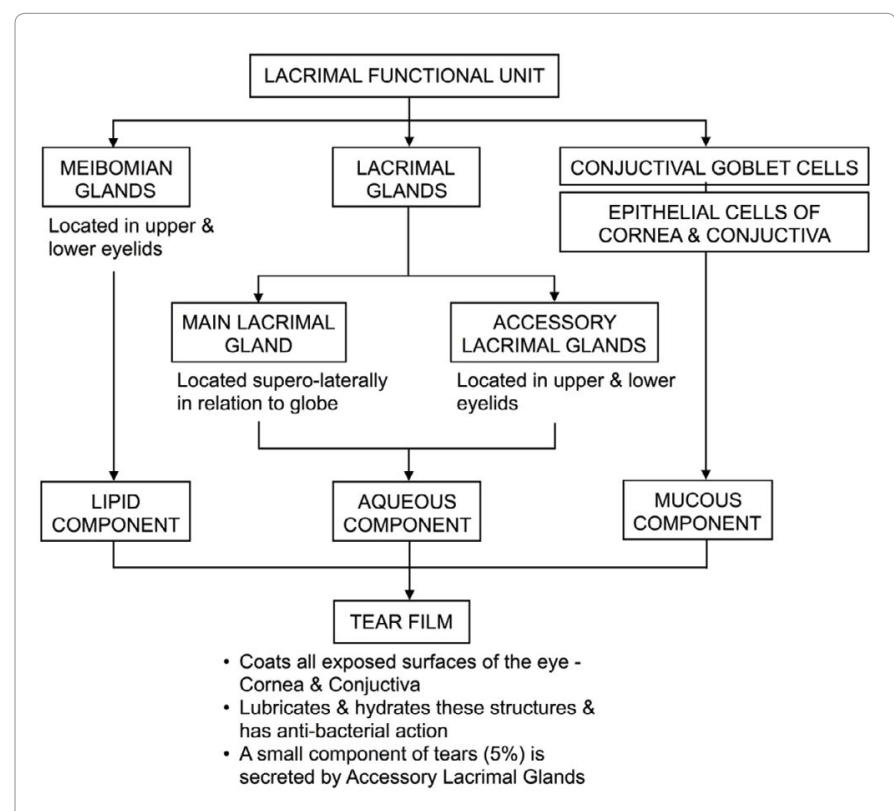

Figure 1: Diagrammatic summary of the normal physiology of the lacrimal functional unit and the role of its subunits in maintaining tear film.

severe chronic DES in a single patient. However, the range of RT dose prescribed was quite variable (15-53.8 Gy) [10]. Older series reported by Bessel et al and Letschert et al also report a threshold dose of 30-40 Gy beyond which the probability of DES rises significantly $[11,12]$.

The incidence for severe DES (defined as sufficient enough to produce vision loss) resulting with higher doses used in the treatment of carcinomas in and around the orbit, in which the eye was included in the treatment field, was reported by Parsons et al [13]. 33 patients were treated with conventional radiation techniques and dose to the lacrimal gland was estimated retrospectively with appropriate dosimetric corrections. They reported that all patients receiving a dose greater than 57 Gy developed dry eye syndrome with vision loss, while $20 \%$ of patients receiving a dose less than 45 Gy developed this complication and the latency of developing dry eye was inversely

${ }^{*}$ Corresponding author: Kundan Singh Chufal, Senior Consultant and Head of Unit (Thoracic \& Paediatric Oncology), Department of Radiotherapy, Rajiv Gandhi Cancer Institute \& Research Centre, Sector-5, Rohini, New Delhi, India, Tel: 0091 98119 96326; Fax: 009111 27051037; E-mail: kundan25@gmail.com

Received March 05, 2018; Accepted March 12, 2018; Published March 16, 2018

Citation: Ahmad I, Chufal KS, Bhatt CP (2018) Not all Tears Imply Sadness: A Concise Review on the Impact of Modern Radiotherapy Techniques in Preventing Radiation Induced Xerophthalmia. J Nucl Med Radiat Ther S9: 001. doi: 10.4172/2155-9619.S9-001

Copyright: (C) 2018 Ahmad I, et al. This is an open-access article distributed under the terms of the Creative Commons Attribution License, which permits unrestricted use, distribution, and reproduction in any medium, provided the original author and source are credited. 
Citation: Ahmad I, Chufal KS, Bhatt CP (2018) Not all Tears Imply Sadness: A Concise Review on the Impact of Modern Radiotherapy Techniques in Preventing Radiation Induced Xerophthalmia. J Nucl Med Radiat Ther S9: 001. doi: 10.4172/2155-9619.S9-001

Page 2 of 5

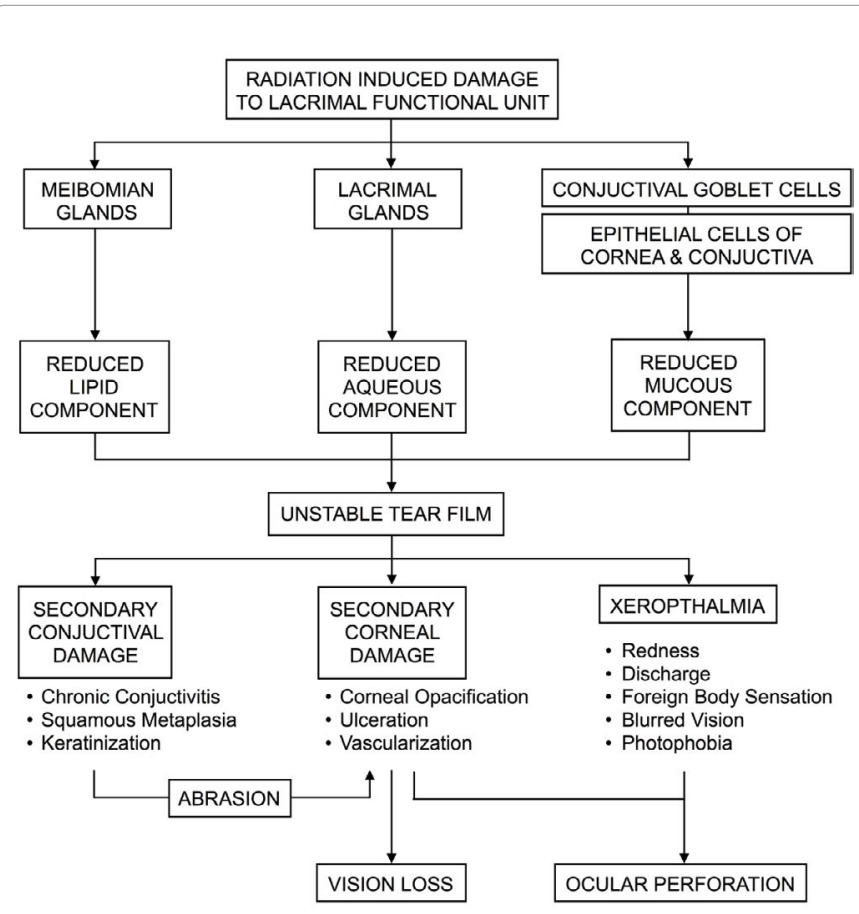

Figure 2: Summary of radiation induced damage to the lacrimal functional unit and its potential consequences. proportional to the total dose received. They also generated a dose effect curve (incorporating data from three other authors who reported on dry eye syndrome), which revealed a $0 \%$ complication probability at doses less than $30 \mathrm{~Gy}$, and $100 \%$ probability at doses greater than 57 Gy. In an update of the data from Parsons et al, Bhandare et al reported on 78 patients with paranasal sinus cancer and the incidence of severe DES with conventional radiation techniques [14]. The dose to lacrimal gland was estimated from conventional treatment plans using CT or CT-MR imaging studies for 54 patients and from phantom dosimetry for remaining patients treated earlier in the series. 51\% (40/78) patients developed dry-eye syndrome leading to visual loss with the latency of developing dry eye syndrome being inversely related to dose per fraction and total dose, in a continuous relationship. The incidence of DES leading to visual loss increased from $6.7 \%$ for doses between $35-40$ Gy to $25 \%$ for $40-45 \mathrm{~Gy}, 50 \%$ for $45-50 \mathrm{~Gy}$, and $90 \%$ for doses greater than $60 \mathrm{~Gy}$. Kaplan-Meier analysis showed a significant decrease in the freedom from DES from $93 \%$ for doses less than 45 Gy to $29 \%$ for doses between 45-59.9 Gy and 3\% for doses greater than $60 \mathrm{~Gy}$. Normal tissue complication probability (NTCP) modeling showed a $5 \%$ incidence for a dose of $34 \mathrm{~Gy}$ and $10 \%$ incidence for a dose of $38 \mathrm{~Gy}$ Another series reported by Jiang et al, evaluated 219 patients treated for nasal and paranasal cancers by conventional treatment techniques, with some patients receiving corneal and/or lacrimal shielding [15] Dose to the corneal-lacrimal complex was estimated from CT scans or reconstructed from isodose curves on patient contours. The 2 year incidence of visual impairment due to damage to corneal-lacrimal complex was $17 \%$ when the lacrimal gland received $42-55$ Gy and

\begin{tabular}{|c|c|c|c|c|c|}
\hline Author & $\mathbf{N}$ & Patient population & RT dose delivered & Technique & Toxicity (Dry Eye Syndrome) \\
\hline Bessel et al. [11] & 115 & Orbital Lymphoma & $\begin{array}{l}40 \mathrm{~Gy} \text { in } 20 \mathrm{Fr} \text { or } 30 \mathrm{~Gy} \text { in } \\
15 \mathrm{Fr}\end{array}$ & Conventional & $\begin{array}{l}\text { Late DES rate with } 6-29 \text { Gy: } 0 \% \text {. } \\
\text { Late DES rate with } 30-39 \text { Gy: } 4.5 \% \text {. } \\
\text { Late DES rate with } 40-49 \text { Gy: } 23 \%\end{array}$ \\
\hline Letschert et al. [12] & 30 & Orbital Lymphoma & $\begin{array}{l}40 \mathrm{~Gy} \text { in } 20 \mathrm{Fr} \text { ( } 20 \text { of } 30 \\
\text { patients). The other patients } \\
\text { received doses ranging from } 20 \\
\text { Gy in } 10 \mathrm{Fr} \text { to } 60 \mathrm{~Gy} \text { in } 30 \mathrm{Fr} \text {. }\end{array}$ & Conventional & $\begin{array}{l}\text { DES rate with less than } 40 \text { Gy: } 0 \% \text {. } \\
\text { DES rate with } 40-43 \text { Gy: } 39 \% \text {. } \\
\text { DES rate with greater than } 43 \text { Gy: } 33 \%\end{array}$ \\
\hline Parsons et al. [13] & 33 & $\begin{array}{l}\text { Nasal cavity, paranasal sinuses, } \\
\text { eye, orbit, nasopharynx, upper } \\
\text { gum or skin tumors (in whom } \\
\text { the eye was included within the } \\
\text { treatment fields) }\end{array}$ & $\begin{array}{l}\text { Variable (as per primary } \\
\text { location and histology) }\end{array}$ & Conventional & $\begin{array}{l}\text { Severe DES with less than } 30 \text { Gy: } 0 \% \text {. } \\
\text { Severe DES with } 30-40 \text { Gy: } 25 \% \text {. Severe DES } \\
\text { with } 40-57 \text { Gy: } 50 \% \text {. } \\
\text { Severe DES with greater than } 57 \text { Gy: } 100 \%\end{array}$ \\
\hline Jiang et al. [15] & 219 & $\begin{array}{l}\text { Nasal and paranasal sinus } \\
\text { tumors }\end{array}$ & $\begin{array}{l}\text { Variable (as per primary } \\
\text { location and histology) }\end{array}$ & Conventional & $\begin{array}{l}\text { Visual impairment due to DES with } 42-55 \text { Gy } \\
\text { (without chemotherapy): } 17 \% \\
\text { Visual impairment due to DES with } 42-55 \text { Gy } \\
\text { (with chemotherapy) or } 56-74.5 \text { Gy (without } \\
\text { chemotherapy): } 81 \% \\
\text { Visual impairment due to DES with } 56-74.5 \text { Gy } \\
\text { (with chemotherapy): } 88 \%\end{array}$ \\
\hline Kennerdell et al. [9] & 54 & Orbital Lymphoma & $\begin{array}{l}24 \mathrm{~Gy} \text { in } 12 \mathrm{Fr} \text { or } 25.5 \mathrm{GY} \text { in } \\
17 \mathrm{Fr}\end{array}$ & Conventional & $\begin{array}{l}\text { Acute: } 50 \% \\
\text { Chronic: } 33 \%\end{array}$ \\
\hline Stafford et al. [10] & 48 & Orbital Lymphoma & $\begin{array}{l}\text { 15-53.8 Gy (fractionation } \\
\text { pattern NR) }\end{array}$ & $\begin{array}{l}\text { Conventional, } \\
\text { Orthovoltage X-rays, } \\
\text { Electrons }\end{array}$ & $\begin{array}{l}\text { Acute: } 4 \% \\
\text { Mild chronic: } 25 \% \\
\text { Severe chronic: } 2 \%\end{array}$ \\
\hline Claus et al. [16] & 32 & $\begin{array}{l}\text { Nasal and paranasal sinus } \\
\text { tumors }\end{array}$ & $60-70 \mathrm{~Gy}$ in $30-35 \mathrm{Fr}$ & IMRT & $\begin{array}{l}\text { Acute DES Grade 1-2: } 100 \% \text {. } \\
\text { Acute DES Grade 3+: } 0 \% . \\
\text { Late DES Grade 1-2: } 35 \% \text {. } \\
\text { Late DES Grade } 3+: 0 \% .\end{array}$ \\
\hline Daly et al. [17] & 36 & $\begin{array}{l}\text { Nasal and paranasal sinus } \\
\text { tumors }\end{array}$ & 70 Gy in $33 \mathrm{Fr}$ & IMRT & $\begin{array}{l}\text { Acute DES: } 0 \% \\
\text { Chronic DES: } 2 \%\end{array}$ \\
\hline Duthoy et al. [18] & 39 & $\begin{array}{l}\text { Nasal and paranasal sinus } \\
\text { tumors }\end{array}$ & $60-70 \mathrm{~Gy}$ in $30-35 \mathrm{Fr}$ & IMRT & $\begin{array}{l}\text { Acute DES grade I-2: } 100 \% \text {. } \\
\text { Acute DES grade } 3+: 0 \% . \\
\text { Chronic DES grade } 1-2: 12.8 \% \text {. } \\
\text { Chronic DES grade } 3+: 5 \%\end{array}$ \\
\hline Sreeraman et al. [21] & 18 & $\begin{array}{l}\text { Nasal and paranasal sinus } \\
\text { tumors }\end{array}$ & $60-70 \mathrm{~Gy}$ in $30-35 \mathrm{Fr}$ & IMRT & $\begin{array}{l}\text { Acute grade } 2+\text { ocular toxicity (including DES): } \\
33 \% \text {. } \\
\text { Late grade } 2+\text { ocular toxicity (including DES): } \\
17 \%\end{array}$ \\
\hline
\end{tabular}


Citation: Ahmad I, Chufal KS, Bhatt CP (2018) Not all Tears Imply Sadness: A Concise Review on the Impact of Modern Radiotherapy Techniques in Preventing Radiation Induced Xerophthalmia. J Nucl Med Radiat Ther S9: 001. doi: 10.4172/2155-9619.S9-001

Page 3 of 5

\begin{tabular}{|c|c|c|c|c|c|}
\hline Muller et al. [24] & 72 & Uveal Melanoma & $50 \mathrm{~Gy}$ in $5 \mathrm{Fr}$ & FSRT & Late DES rate: $13.9 \%$ \\
\hline Dirix et al. [20] & 84 & $\begin{array}{l}\text { Nasal and paranasal sinus } \\
\text { tumors }\end{array}$ & $60-66$ Gy in $30-33 \mathrm{Fr}$. & IMRT & $\begin{array}{l}\text { Acute DES grade } 1-2: 30 \% \text {. } \\
\text { Acute DES grade } 3+: 0 \% \text {. } \\
\text { Late DES grade } 1-2: 7.7 \% \text {. } \\
\text { Late DES grade } 3+: 0 \% .\end{array}$ \\
\hline Weigner et al. [19] & 52 & $\begin{array}{l}\text { Nasal and paranasal sinus } \\
\text { tumors }\end{array}$ & $\begin{array}{l}\text { 60-66 Gy in } 30 \mathrm{Fr} \text {. SRS Boost } \\
\text { for gross residual disease: } 8 \mathrm{~Gy} \\
\text { in single Fr or } 10 \mathrm{~Gy} \text { in } 2 \mathrm{Fr}\end{array}$ & IMRT & $\begin{array}{l}\text { Acute DES grade } 1-2: 37 \% \text {. } \\
\text { Acute DES grade } 3+: 0 \% \text {. } \\
\text { Late DES grade } 1-2: 11.5 \% \text {. } \\
\text { Late DES grade } 3+: 0 \% \text {. }\end{array}$ \\
\hline Bhandare et al. [14] & 78 & $\begin{array}{l}\text { Nasal cavity, paranasal sinuses, } \\
\text { eye, orbit, nasopharynx, upper } \\
\text { gum or skin tumors (in whom } \\
\text { the eye was included within the } \\
\text { treatment fields) }\end{array}$ & $\begin{array}{l}\text { Variable (as per primary } \\
\text { location and histology) }\end{array}$ & Conventional & $\begin{array}{l}\text { DES with less than } 35 \text { Gy: } 0 \% \text {. } \\
\text { DES with } 35-39.9 \text { Gy: } 6 \% \\
\text { DES with } 45-49.9 \text { Gy: } 50 \% \text {. } \\
\text { DES with } 60-64.99 \text { Gy: } 90 \% \text {. } \\
\text { DES with greater than } 65 \text { Gy: } 100 \%\end{array}$ \\
\hline Duprez et al. [22] & 130 & $\begin{array}{l}\text { Nasal and paranasal sinus } \\
\text { tumors }\end{array}$ & $70 \mathrm{~Gy}$ in $33 \mathrm{Fr}$ & IMRT & $\begin{array}{l}\text { Acute DES grade } 1-2: 27 \% \text {. } \\
\text { Acute DES grade } 3+: 1 \% \text {. } \\
\text { Late DES grade } 1-2: 25.6 \% \text {. } \\
\text { Late DES grade } 3+: 0 \% .\end{array}$ \\
\hline Batth et al. [23] & 40 & $\begin{array}{l}\text { Nasal and paranasal sinus } \\
\text { tumors }\end{array}$ & $66 \mathrm{~Gy}$ in $33 \mathrm{Fr}$ & IMRT & $\begin{array}{l}\text { Acute grade } 1-2 \text { ocular toxicity (including DES): } \\
21 \% \text {. } \\
\text { Acute grade } 3+\text { ocular toxicity (including DES): } \\
18 \% . \\
\text { Late grade } 1-2 \text { ocular toxicity (including DES): } \\
18 \% \text {. } \\
\text { Late grade } 3+\text { ocular toxicity (including DES): } \\
13 \% \text {. }\end{array}$ \\
\hline Thariat et al. [25] & 853 & Uveal Melanoma & $52 \mathrm{~Gy}$ in $4 \mathrm{Fr}$ & Proton Therapy & $\begin{array}{l}\text { All grades DES incidence at } 1 \mathrm{yr}, 2 \mathrm{yr} \text { and } \\
5 \mathrm{yr}: 6 \%, 11.2 \% \text { and } 23 \% \text {, respectively. } \\
\text { Severe DES incidence at } 1 \mathrm{yr}, 2 \mathrm{yr} \text { and } 5 \mathrm{yr} \text { : } \\
2.1 \%, 4.8 \% \text { and } 10.9 \% \text {, respectively. }\end{array}$ \\
\hline
\end{tabular}

Table 1: Summary of the literature on radiation induced dry eye syndrome. Abbreviations: DES: Dry Eye Syndrome; Gy: Gray; Fr: Fractions; FSRT: Fractionated Stereotactic Radiotherapy; IMRT: Intensity Modulated Radiotherapy- RT: Radiotherapy; SRS: Stereotactic Radio Surgery.

$81 \%$ when the lacrimal gland received 56-74.5 Gy. These studies laid the foundation for understanding RT induced damage to the lacrimal functional unit, but are not without limitations. The data primarily corresponds to the era of conventional radiotherapy, consequently the biggest limitation being that either the dose received by the whole orbit or point dose estimates were correlated with incidence of DES.

A few series have reported on the incidence of DES with intensity modulated radiotherapy (IMRT) used in the management of nasal and paranasal carcinomas, without explicitly defining constraints for main lacrimal gland during treatment planning [16-20]. In these series the incidence of any grade of DES ranged from $2 \%$ to $35 \%$ and the rate of DES leading to vision loss was nil. Dirix et al reported on a retrospective comparison between IMRT and conventional RT technique for postoperative management of nasal cavity/paranasal sinus cancers [20]. They observed a significantly lower rate of DES of $7.7 \%$ with IMRT (compared to $31.6 \%$ with conventional technique, $\mathrm{p}=0.007$ ). While fortuitous lacrimal gland sparing may be considered a feature of IMRT due to rapid dose fall-off beyond the planning target volume, objective data on the dose-response relationship of the lacrimal gland is needed. Three studies have reported on incidence of DES after delineating the main lacrimal gland during treatment planning for IMRT. Sreeraman et al analyzed grade 2 or higher ocular toxicity (including DES) and dose volume histograms for lacrimal gland [21]. They reported a significant correlation between $\mathrm{V}_{30 \mathrm{~Gy}}>50 \%$ and risk for acute and late grade 2 or more ocular toxicity. Duprez et al have reported on incidence of DES after delineating and placing a constraint $\left(\mathrm{D}_{50 \%}<30 \mathrm{~Gy}\right)$ on the main lacrimal gland [22]. They reported acute grade 2 or less DES in $27 \%$ of patients and late grade 2 or less DES in $25.6 \%$ of patients. Batth et al reported on the dose response relationship between dose to bilateral lacrimal glands and ocular toxicity [23]. A significant relationship was demonstrated between maximum dose (Dmax) and acute ocular toxicity, with every 1 Gy increase in $\mathrm{D}_{\max }$ increasing the probability for a higher toxicity grade by $23 \%(\mathrm{p}<0.001)$. Similarly, a significant relationship was demonstrated between $\mathrm{V}_{20 \mathrm{~Gy}}$ and late ocular toxicity, with every $1 \%$ increase in $\mathrm{V}_{20 \mathrm{~Gy}}$ increasing the probability of developing grade $1+$ late toxicity by $4 \%(\mathrm{p}=0.002)$.

At the higher end of the dose spectrum, a few series have explored the incidence of DES with hypofractionated radiotherapy for uveal melanomas. Muller et al reported on incidence of DES and abnormal schirmer test in patients with uveal melanoma treated with fractionated stereotactic radiotherapy (FSRT) [24]. Lacrimal gland mean dose $\left(\mathrm{D}_{\text {mean }}\right)$ exceeding $8 \mathrm{~Gy} /$ fraction and median dose $\left(\mathrm{D}_{50 \%}\right)$ exceeding $10 \mathrm{~Gy} /$ fraction resulted in $50 \%$ probability of DES. Similarly, lacrimal gland mean dose $\left(\mathrm{D}_{\operatorname{mean}}\right)$ exceeding $6 \mathrm{~Gy} /$ fraction and median dose $\left(\mathrm{D}_{50 \%}\right)$ exceeding $7 \mathrm{~Gy} /$ fraction resulted in $50 \%$ probability of abnormal schirmer test. Thariat et al have recently reported on the single largest series of patients with uveal melanoma treated with proton therapy [25]. The 5 year incidence of DES and severe DES was $23 \%$ and $10.9 \%$, respectively. The median dose to lacrimal gland in patients with severe DES was $50.7 \mathrm{~Gy}$.

While the data on dose-response relationship of ocular toxicity with lacrimal gland dose are valuable, they are susceptible to inter-observer variations in delineation of very small structures [26]. Additionally, due to its relatively superficial location and small size, calculated dose parameters are susceptible to various technical issues (e.g. differences in the dose calculation algorithm, CT slice thickness, pixel width, dose grid voxel width, dose-volume histogram calculation resolution and surface dose calculation inaccuracies) $[27,28]$. To counteract the issue of interobserver a delineation guide on CT images is available [29]. Figure 3 demonstrates delineation of lacrimal gland with the aid of MRI. Figure 4 demonstrates the variation in delineating the main lacrimal gland on MRI versus CT and examples of lacrimal gland sparing achieved with Volumetric Modulated Arc Therapy (VMAT). 
Citation: Ahmad I, Chufal KS, Bhatt CP (2018) Not all Tears Imply Sadness: A Concise Review on the Impact of Modern Radiotherapy Techniques in Preventing Radiation Induced Xerophthalmia. J Nucl Med Radiat Ther S9: 001. doi: 10.4172/2155-9619.S9-001

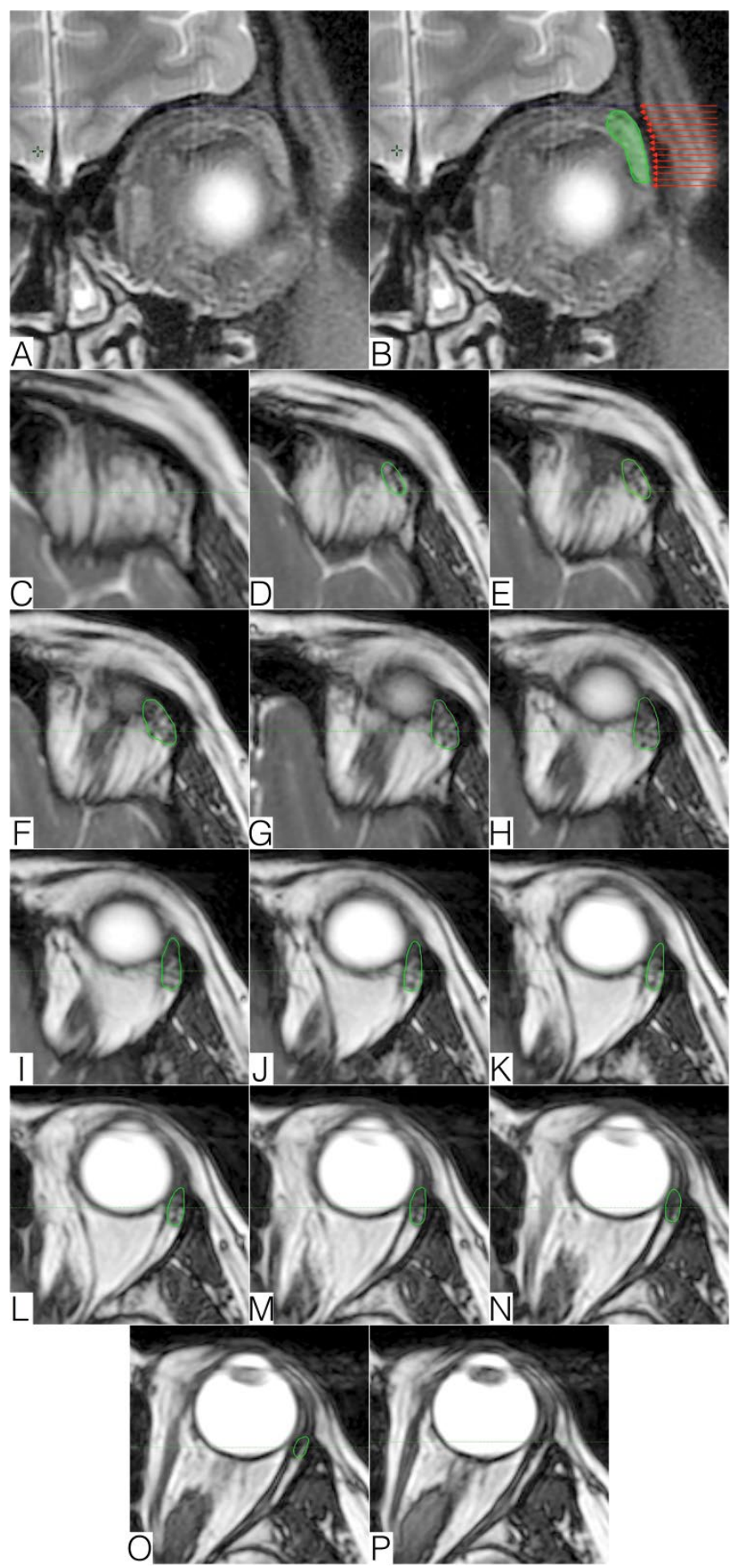

Figure 3: Delineation of lacrimal gland on MRI. (A, B) Coronal T2 Fat Suppressed MRI images with lacrimal gland delineated in green. Horizontal red arrows represent axial sections shown in subsequent images. $(C-P)$ Axial FIESTA (Fast Imaging Employing STeady-state Acquisition) MRI sequence arranged in cranio-caudal order. Lacrimal gland is delineated in green. Also note an irregular growth on the optic nerve $(\mathrm{N}, \mathrm{O}, \mathrm{P})$ which is an optic nerve sheath meningioma.

The authors recommend that $\mathrm{D}_{\max }$ to orbit be limited to $40 \mathrm{~Gy}$ when delivering treatment with conventional techniques. For IMRT/ VMAT treatment the authors recommend lacrimal gland delineation on CT (with MRI co-registration if available). If feasible, $\mathrm{D}_{\max }$ should

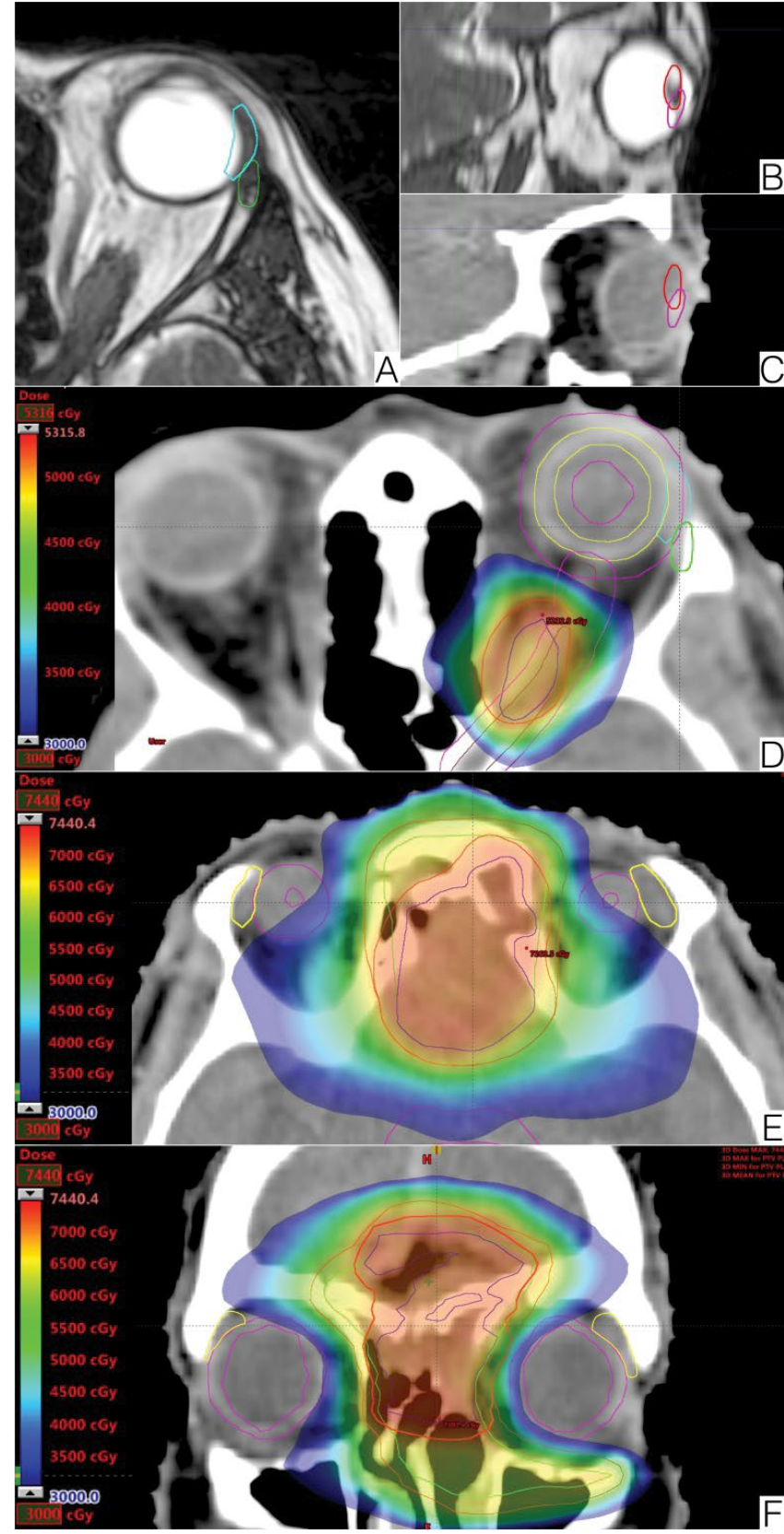

Figure 4: (A-C) MRI and CT Images of patient shown in figure 3, demonstrating discrepancy between delineation of lacrimal gland on MRI versus CT. MRI delineated lacrimal gland is shown in green and CT delineated lacrimal gland is shown in cyan. This discepancy arose due to difference in eye position during both image acquisition procedures. This can be appreciated by noting the position of the lens on both scans. MRI delineated lens is shown in red and CT delineated lens is shown in purple. (D) Axial treatment planning image with VMAT of the patient shown in figure 3, with the lower limit of the dose color wash set to $30 \mathrm{~Gy}$, demonstrating sparing of the left lacrimal gland [shown in green (MRI delineated) and cyan (CT delineated)]. The patient received $50.4 \mathrm{~Gy}$ in $28 \mathrm{Fr}$. (E, F) Axial and coronal treatment planning images with VMAT, of a patient with nasal squamous cell carcinoma with intracranial extension. The lower limit of the dose color wash is set to $30 \mathrm{~Gy}$, demonstrating adequate sparing of bilateral lacrimal glands (shown in yellow contours). The patient received $70 \mathrm{~Gy}$ in $35 \mathrm{Fr}$. 
Citation: Ahmad I, Chufal KS, Bhatt CP (2018) Not all Tears Imply Sadness: A Concise Review on the Impact of Modern Radiotherapy Techniques in Preventing Radiation Induced Xerophthalmia. J Nucl Med Radiat Ther S9: 001. doi: 10.4172/2155-9619.S9-001

be limited to $30 \mathrm{~Gy}$ and emphasis should be placed to minimize $\mathrm{V}_{20 \mathrm{~Gy}}$ as much as possible. If $\mathrm{D}_{\max }$ cannot be kept below $30 \mathrm{~Gy}$, then planning should aim to limit $\mathrm{D}_{\max }$ to $40 \mathrm{~Gy}$ and achieve $\mathrm{D}_{50 \%}<30 \mathrm{~Gy}$.

In conclusion, radiation induced damage to the lacrimal functional unit is an important complication of radiotherapy directed at or in proximity to the orbit, with the potential to reduce functional vision. Advances in modern radiotherapy have resulted in significantly lower rates of DES, requiring meticulous attention to detail in every step of the treatment planning process.

\section{References}

1. Sanfilippo NJ, Formenti SC (2013) Perez \& Brady's principles and practice of radiation oncology. (6th edn), Lippincott Williams \& Wilkins, Philadelphia, London, Toranto.

2. Lemp MA, Baudouin C, Baum J, Dogru M, Foulks GN, et al. (2007) The definition and classification of dry eye disease: Report of the Definition and Classification Subcommittee of the International Dry Eye Workshop. Ocul Surf 5: 75-92.

3. Stern ME, Beuerman RW, Fox RI, Gao J, Mircheff AK, et al. (1998) The pathology of dry eye: The interaction between the ocular surface and lacrimal glands. Cornea 17: 584-589.

4. Stern ME, Gao J, Siemasko KF, Beuerman RW, Pflugfelder SC (2004) The role of the lacrimal functional unit in the pathophysiology of dry eye. Exp Eye Res 78: 409-416.

5. Roth JO, Brown NI, Catterall MA, Beal AN (1976) Effects of fast neutrons on the eye. $\mathrm{Br} \mathrm{J}$ Ophthalmol 60: 236-244.

6. Jeganathan VS, Wirth A, MacManus MP (2011) Ocular risks from orbital and periorbital radiation therapy: A critical review. Int J Radiat Oncol Biol Phys 79: 650-659.

7. Karp LA, Streeten BW, Cogan DG (1979) Radiation-induced atrophy of the meibomian glands. Arch Ophthalmol 97: 303-305.

8. Stephens LC, Schultheiss TE, Peters LJ, Ang KK, Gray KN (1988) Acute radiation injury of ocular adnexa. Arch Ophthalmol 106: 389-391.

9. Kennerdell JS, Flores NE, Hartsock RJ (1999) Low-dose radiotherapy for lymphoid lesions of the orbit and ocular adnexa. Ophthal Plast Reconstr Surg 15: $129-133$

10. Stafford SL, Kozelsky TF, Garrity JA, Kurtin PJ, Leavitt JA, et al. (2001) Orbita lymphoma: Radiotherapy outcome and complications. Radiother Oncol 59: 139-144.

11. Bessell EM, Henk JM, Whitelocke RA, Wright JE (1987) Ocular morbidity after radiotherapy of orbital and conjunctival lymphoma. Eye 1: 90-96.

12. Letschert JG, Gonzalez DG, Oskam J, Koornneef L, Van Dijk JD, et al. (1991) Results of radiotherapy in patients with stage I orbital non-Hodgkin's lymphoma. Radiother Oncol 22: 36-44.

13. Parsons JT, Bova FJ, Fitzgerald CR, Mendenhall WM, Million RR (1994) Severe dry-eye syndrome following external beam irradiation. Int J Radiat Oncol Biol Phys 30: 775-780.
14. Bhandare N, Moiseenko V Song WY, Morris CG, Bhatti MT, et al. (2012) Severe dry eye syndrome after radiotherapy for head-and-neck tumors. Int $J$ Radiat Oncol Biol Phys 82: 1501-1508.

15. Jiang GL, Tucker SL, Guttenberger R, Peters LJ, Morrison WH, et al. (1994) Radiation-induced injury to the visual pathway. Radiother Oncol 30: 17-25.

16. Claus F, Boterberg T, Ost P, De Neve W (2002) Short term toxicity profile for 32 sinonasal cancer patients treated with IMRT. Can we avoid dry eye syndrome? Radiother Oncol 64: 205-208.

17. Daly ME, Chen AM, Bucci MK, El-Sayed I, Xia P, et al. (2007) Intensitymodulated radiation therapy for malignancies of the nasal cavity and paranasal sinuses. Int J Radiat Oncol Biol Phys 67: 151-157.

18. Duthoy W, Boterberg T, Claus F, Ost P, Vakaet L, et al. (2005) Postoperative intensity-modulated radiotherapy in sinonasal carcinoma. Cancer 104: 71-82.

19. Wiegner EA, Daly ME, Murphy JD, Abelson J, Chapman CH, et al. (2012) Intensity-modulated radiotherapy for tumors of the nasal cavity and paranasal sinuses: Clinical outcomes and patterns of failure. Int J Radiat Oncol Biol Phys 83: $243-251$

20. Dirix P, Vanstraelen B, Jorissen M, Poorten V, Nuyts S (2010) Intensitymodulated radiotherapy for sinonasal cancer: Improved outcome compared to conventional radiotherapy. Int J Radiat Oncol Biol Phys 78: 998-1004.

21. Sreeraman R, Doshi S, Cui J, Mathai M, Yang CC, et al. (2009) Clinicaldosimetric analysis of lacrimal gland dysfunction among patients treated by intensity-modulated radiotherapy for sinonasal tumors. Int J Radiat Oncol Bio Phys 75: S417-418.

22. Duprez F, Madani I, Morbée L, Bonte K, Deron P, et al. (2012) IMRT for sinonasal tumors minimizes severe late ocular toxicity and preserves disease control and survival. Int J Radiat Oncol Biol Phys 83: 252-259.

23. Batth SS, Sreeraman R, Dienes E, Beckett LA, Daly ME, et al. (2013) Clinical dosimetric relationship between lacrimal gland dose and ocular toxicity afte intensity-modulated radiotherapy for sinonasal tumours. $\mathrm{Br} \mathrm{J}$ Radiol 86 : 20130459

24. Muller K, Nowak PJ, Naus N, de Pan C, van Santen CA, et al. (2009) Lacrima gland radiosensitivity in uveal melanoma patients. Int $\mathrm{J}$ Radiat Oncol Biol Phys 74: 497-502.

25. Thariat J, Maschi C, Lanteri S, Peyrichon ML, Baillif S, et al. (2017) Dry eye syndrome following proton therapy of ocular melanomas. Int J Radiat Onco Biol Phys 98: 142-151.

26. Brouwer CL, Steenbakkers RJ, Bourhis J, Budach W, Grau C et al. (2015) CTbased delineation of organs at risk in the head and neck region: DAHANCA EORTC, GORTEC, HKNPCSG, NCIC CTG, NCRI, NRG Oncology and TROG consensus guidelines. Radiother Oncol 117: 83-90.

27. Ebert MA, Haworth A, Kearvell R, Hooton B, Hug B, et al. (2010) Comparison of DVH data from multiple radiotherapy treatment planning systems. Phys Med Biol 55: N337-346.

28. Kry SF, Smith SA, Weathers R, Stovall M (2012) Skin dose during radiotherapy: A summary and general estimation technique. J Appl Clin Med Phys 13: 20-34

29. Freedman L, Sidani C (2015) A Radiation Oncologist's Guide to Contouring the Lacrimal Gland. Pract Radiat Oncol 5: e697-698. 